\author{
References \\ 1 Affara NA, Ferguson-Smith MA, Magenis RE, et al. Mapping \\ the testis determinants by an analysis of $\mathrm{Y}$-specific sequences in \\ males with apparent $\mathrm{XX}$ and $\mathrm{XO}$ karyotypes and females with \\ XY karyotypes. Nucleic Acids Res 1987;15:7325-41. \\ 2 Page DC, Mosher R, Simpson EM, et al. The sex determining \\ region of the human $\mathrm{Y}$ chromosome encodes a finger protein. \\ Cell 1987;51:1091-104. \\ ${ }^{3}$ Pearson PL, Kidd KK, Willard HF. Report of the committee on \\ human gene mapping by recombinant DNA techniques. Cyto- \\ genet Cell Genet 1988;46,331-81. \\ 4 Pritchard CA, Goodfellow PJ, Goodfellow PN. Isolation of a \\ sequence which maps close to the human sex determining gene. \\ Nucleic Acids Res 1987;15:6159-69.
}

${ }^{5}$ Clayton GW, Darrel Smith J, Rosenberg HS. Familial true hermaphroditism in pre and post pubertal genetic females. Hormonal and morphological studies. Journal of Clinical Endocrinology 1958;18:1349-58.

6 Skordis NA, Stetka DG, MacGillivray MH, Greenfield SP. Familial 46XX males coexisting with familial 46XX true hermaphrodites in same pedigree. $J$ Pediatr 1987;110:244-8.

${ }^{7}$ Ferguson-Smith MA. Genes on the $\mathrm{X}$ and $\mathrm{Y}$ chromosomes controlling sex. Br Med J 1988;297:635-6.

Correspondence to Dr DB Grant, Hospital for Sick Children, Great Ormond Street, London WC1N 3JH.

Accepted 9 January 1989

\title{
Psychological care of survivors of a fire
}

\author{
T JAFFA* AND G SUPRAMANIAM $\dagger$ \\ ${ }^{*}$ Watford Child and Family Clinic, and †Watford General Hospital
}

SUMMARY A mother and daughter were the sole survivors of a house fire. Support, maintenance of the parent-child relationship, and monitoring and facilitating the grieving process in a way that was consistent with the developmental stages of the patients were the basis of management.

\section{Case report}

Four members of an Asian family of six died in a fire, started by a gas heater while they slept. They were the father, two daughters aged 11 and 2 , and a son aged 9. The mother and 7 year old daughter were admitted to the intensive care unit of the district general hospital. They were both suffering from extensive heat and inhalation injuries, and required ventilatory support-the mother for several hours, and the daughter for several days, during which she was sedated and paralysed.

The mother spoke little English, and so most communication was through her local authority social worker who spoke her language. Visitors told the mother that the other members of her family were in another hospital. Three days later she was told of their deaths. She seemed numbed, shed few tears, and asked no questions. Five days after the fire, the daughter had still not been told what had happened. She played quietly with nursing staff and often seemed frightened, but asked no questions about her burns, her presence in hospital, or the whereabouts of her father, brother, and sisters. She avoided contact with her mother. The mother's father was unable to be with her for another week. Physically, mother and daughter were well enough to be transferred from the intensive care unit.

\section{Psychological aspects of further management}

Because we thought that a multidisciplinary team approach would be the best way to help the patients, the paediatrician (GS), child psychiatrist (TJ), social worker, and nursing staff met regularly. These meetings helped us to acknowledge our feelings of hopelessness and our own memories of loss. We were then more able to separate these from our thinking about the needs of this mother and daughter.

We wished to support the relationship between the mother and daughter, so we ensured that when they were transferred they went to adjacent wards so that they could spend as much time as possible together. We also attempted to support their relationship by encouraging the mother in her role as a parent. There were aspects of hospital routine which made this difficult. The authority of a mother and the authority of hospital staff sit together somewhat uneasily, particularly when both the mother and her daughter are inpatients. In this case the mother's authority was undermined when the staff, despite the reluctance of the mother (who was suffering her own psychological injury), told the daughter about the fire and the deaths.

The daughter needed to know about the fire and deaths as soon as possible to end her uncertainty, to allow her to start grieving, and to avoid her hearing inaccurate accounts from other patients. It was 
apparent that both mother and daughter were numbed by their experience in the fire, and that any information given to them would have to be repeated, probably several times. We went to the mother's cubicle in the intensive care unit. She seemed anxious and a little drowsy, her face extensively marked by superficial burns. She was reluctant to talk about the fire and the deaths. The daughter was brought into the cubicle. She seemed frightened and withdrawn. Her face too was covered by superficial burns. She withdrew when her mother tried to hold her. GS asked about their memories of the fire. The daughter listened intently, holding on to the nurse and saying nothing. Slowly and clearly he went through the details as far as they were known, asking further questions, all unanswered. Mother and daughter looked increasingly frightened and distressed. The daughter kept her distance from her mother. After several minutes the distress in the room became unbearable and the daughter was returned to her own bed. Members of the same small staff group discussed the fire again with them on subsequent days.

Gradually their numbness was replaced, initially by disbelief and some anger (on the part of the mother), and then by tears. The mother talked about the fire and deaths with her daughter and the two of them became physically and emotionally closer. They talked about the dead family members, crying and reminiscing. They visited the burnt out shell of their house. The daughter worked through the tragedy in her drawings which included houses and symbolic representations of fire. This grief work was accomplished by the mother and daughter with the help of relatives and the local community. The contribution of GS and TJ in meetings with the family and with the multidisciplinary team was to provide further support and reassurance that the grief process was healthy and normal..$^{1-3}$ Monitoring the progress of mother and daughter through the stages of shock, protest, and despair, ${ }^{2}$ and noting the signs of recovery, TJ was able to confirm that more specialised help, as would be appropriate for pathological grief, was not necessary. GS, who was present at all these meetings, was able not only to add his own support and encouragement, but-also to model an acceptance of the understanding and knowledge brought by TJ. These meetings also showed that the staff were working as a team, which reduced the risk of some staff being seen as good and some as bad, a phenomenon that can lead to actual conflict and splitting within the staff group.

Exploration of the daughter's understanding of death and its consequences provided a set of words and concepts, the meaning of which was known to her, and to the staff talking to her. She soon began talking about her father being in heaven and made it clear that she knew he would not be returning. Staff were then able to talk with her about her feelings concerning her dead family. Some children who are not much younger than this girl may have a different understanding of death; they may believe it to be reversible. They may worry mostly about their separation from the dead loved one, or about their belief that they have killed them by wishing them dead in an angry moment. Exploring the belief systems and particular preoccupations of a child are prerequisites to being able to help them in grief.

\footnotetext{
References

${ }^{1}$ Parkes CM. Bereavement: studies of grief in adult life. Harmondsworth: Penguin, 1986.

2 Bowlby J. Pathological mourning and childhood mourning. J Am Psychoanal Assoc 1963;11:500-41.

${ }^{3}$ Lieberman S, Black D. Loss, mourning and grief. In: Bentovim A, ed. Family therapy; complementary frameworks of theory and practise. London: Academic Press, 1982.
}

Correspondence to Dr G Supramaniam, Watford General Hospital, Watford, Hertfordshire WD1 8HB.

Accepted 16 March 1989 